\title{
Penerapan Metode AHP Untuk Menentukan Kualitas Pakaian Jadi di Industri Garment
}

\author{
Rizal Rachman \\ STMIK Nusa Mandiri Jakarta \\ JI. Damai No. 8 ( Margasatwa) Pasar Minggu Jakarta Selatan \\ Email: rizalkhaizuran@gmail.com
}

\begin{abstract}
Abstrak
Dalam era globalisasi, persaingan bisnis menjadi sangat tajam, baik dipasar nasional maupun di pasar internasional. Meningkatnya intensitas persaingan dan jumlah pesaing juga menuntut setiap perusahaan untuk selalu memperhatikan kebutuhan dan keinginan konsumen serta berusaha memenuhi apa yang mereka harapkan dengan cara yang lebih memuaskan dari pada yang dilakukan para pesaing. Kualitas merupakan faktor terpenting untuk menghasilkan standart mutu dalam mengambil keputusan. Selama ini di perusahaan hanya mengandalkan perhitungan manual untuk sistem penunjang keputusan. Biasanya penilaian terhadap kualitas suatu jenis pakaian biasanya bergantung pada jenis bahannya. Padahal bukan hanya bahan pakaian saja yang bisa menjadi acuan kualitas. Berbagai hal detail lainnya juga patut menjadi perhatian, misalnya bagian jahitan. Maka dari itu peneliti akan membuat perhitungan dengan menggunakan metode AHP (Analytic Hierarchi Process) dengan mendefinisikan masalah, pembuatan struktur hierarki serta menentukan kriteria-kriteria dan alternatif-alternatif pilihan. Selanjutnya menghitung nilai Eigen Vector dan menguji konsistensinya. Hasil penelitian menunjukkan sistem penunjang keputusan yang digunakan untuk menentukan kualitas pakaian jadi sudah dapat melakukan perhitungan dengan metode AHP lebih cepat dibandingkan perhitungan secara manual sehingga bisa lebih efesien dan tingkat keakuratan data.
\end{abstract}

Kata kunci : SPK, Metode AHP, Kualitas.

\begin{abstract}
In the era of globalization, business competition becomes very sharp, both in the national market and in the international market. Increased intensity of competition and the number of competitors also requires every company to always pay attention to the needs and desires of consumers and trying to meet what they expect in a more satisfactory than the competitors. Quality is the most important factor to produce quality standards in making decisions. So far in the company only rely on manual calculations for decision support systems. Usually an assessment of the quality of a particular type of clothing usually depends on the type of material. Though not only clothing material that can be a reference quality. Various other details also deserve attention, for example the stitching section. Therefore, the researcher will make the calculation by using AHP (Analytic Hierarchi Process) method by defining problem, making hierarchy structure and determining criteria and alternative choices. Next calculate the value of Eigen Vector and test its consistency. The results showed that decision support system used to determine the quality of apparel has been able to perform calculations with AHP method faster than the calculation manually so that it can be more efficient and the level of data accuracy.
\end{abstract}

\section{Keywords: SPK, Metode AHP, Quality.}

\section{Pendahuluan}

Kualitas menjadi faktor dasar keputusan konsumen dalam banyak produk dan jasa. Gejala ini meluas, tanpa membedakan jenis konsumen itu perseorangan, kelompok, kelompok industri, program pertahanan militer, atau toko pengecer, sehingga kualitas adalah faktor kunci yang membawa keberhasilan bisnis, pertumbuhan, dan peningkatan posisi bersaing. Keuntungan besar pada investasi dari program jaminan kualitas yang efektif akan memberikan kenaikan keuntungan kepada perusahaan yang menggunakan kualitas sebagai strategi bisnisnya. Program 
jaminan kualitas yang efektif dapat menghasilkan kenaikan penetrasi pasar, produktivitas lebih tinggi, dan biaya pembuatan barang dan jasa keseluruhan yang lebih rendah (Montgomery, 2009).

Ketersedian bahan baku berkualitas memegang peranan sangat penting dari seluruh rangkaian kegiatan produksi suatu perusahaan industri terutama untuk menghasilkan produk yang berkualitas tinggi dan banyak diminati oleh konsumen (Prayoga, 2017).

Banyak para pelaku usaha pakai jadi sering mengalami kesulitan dalam menentukan kualitas pakaian jadi. Hal ini disebabkan kualitas yang bermacam-macam dan permintaan konsumen yang berbedabeda. Pakaian jadi mempunyai tingkat kualitas yang berbeda-beda. Hal ini dikarenakan setiap pakaian mempunyai tingkat kualitas kain, jahitan, dan ukuran berbeda. Sehingga para pelaku usaha mengalami kesulitan dalam menentukan kualitas pakaian sesuai dengan permintaan konsumen. Oleh karena itu diperlukan suatu sistem yang dapat memberikan informasi tentang kualitas pakaian, sehingga dapat membantu pengusaha garment dalam pengambilan keputusan untuk menentukan kualitas pakaian jadi sesuai dengan permintaan konsumen (Darmanto,2014).

Sistem Pendukung Keputusan (Decission Support System) adalah sistem informasi berbasis komputer yang menyediakan dukungan informasi yang interaktif bagi manajer dan praktisi bisnis selama proses pengambilan keputusan (O'Brien, 2008).

SPK dibangun tentunya mempunyai tujuan yang ingin dicapai oleh seorang pembuat keputusan. Tujuan SPK adalah sebagai "second opinion" atau "information sources" sebagai bahan pertimbangan seorang manajer sebelum memutuskan kebijakan tertentu. SPK dibangun oleh tiga komponen Supriyanto (2008), yaitu:

1. Database

Sistem Database adalah kumpulan semua data yang dimiliki oleh perusahaan baik data dasar maupun transaksi sehari-hari.

2. Model base

Model base adalah suatu model yang merepresentasikan permasalahan dalam format kuantitatif.

3. Software System

Software System adalah paduan antara database dan model base, setelah sebelumnya direpresentasikan ke dalam bentuk model yang dimengerti oleh sistem komputer.

Analytical Hierarchy Process (AHP) merupakan suatu model pendukung keputusan yang menguraikan masalah multi faktor atau multi kriteria yang kompleks menjadi suatu hirarki (Saaty,2010). Hirarki didefinisikan sebagai suatu representasi dari sebuah permasalahan yang kompleks dalam suatu struktur multi level dimana level pertama adalah tujuan, yang diikuti level faktor, kriteria, sub kriteria, dan seterusnya ke bawah hingga level terakhir dari alternatif. Dengan hirarki, suatu masalah yang kompleks dapat diuraikan ke dalam kelompok-kelompoknya yang kemudian diatur menjadi suatu bentuk hirarki sehingga permasalahan akan tampak lebih terstruktur dan sistematis sering digunakan sebagai metode pemecahan masalah dibanding dengan metode yang lain karena alasanalasan sebagai berikut (Saragih,2013): Struktur yang berhirarki, sebagai konsekuesi dari kriteria yang dipilih, sampai pada subkriteria yang paling dalam dan Memperhitungkan validitas sampai dengan batas toleransi inkonsistensi berbagai kriteria dan alternatif yang dipilih oleh pengambil keputusan. Memperhitungkan daya tahan output analisis sensitivitas pengambilan keputusan.

Penelitian sebelumnya mengenai Sistem Penunjang Keputusan tentang Metode AHP adalah hasil penelitian oleh (Abadi, 2016) menyatakan bahwa Performance alternatif-alternatif yang berkaitan dengan kriteria dibentuk dan dapat memberikan rekomendasi untuk penentuan penerima bantuan dana untuk sekolah menengah berdasarkan analisis pada kriteria dan subkriteria yang ditetapkan. Hasil penelitian oleh (Sestri, 2013) menghasilkan AHP mampu membantu penyelesaian permasalahan penilaian kinerja Dosen dengan akurasi tinggi memiliki kebenaran $90 \%$ sehingga data sudah konsisten. Selanjutnya penelitia oleh (Lemantara,2013) menghasilkan kombinasi AHP dan Promethee terbukti lebih baik daripada hasil pemeringkatan dari metode AHP atau Promethee saja. Hal ini dikarenakan kelebihan dari masing-masing metode digunakan.

\section{Metode Penelitian}

Data yang digunakan dalam penelitian ini adalah data periode Juni 
tahun 2018 yang berkaitan dengan kualitas pakaian jadi.

Tahapan-tahapan dalam AHP ( Analytic Hierarchy process ):

1. Mendefinisikan masalah dan menentukan solusi yang diinginkan.

2. Membuat struktur hierarki yang diawali dengan tujuan umum, dilanjutkan dengan kriteria-kriteria dan alternatif- alternatif pilihan.

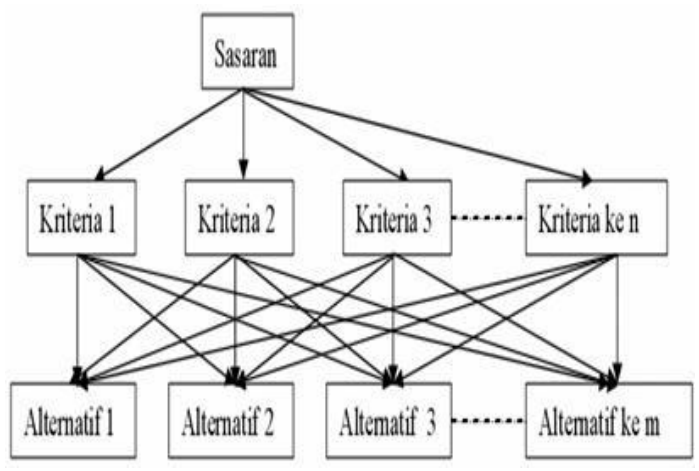

Gambar 1.

Struktur Hierarki AHP

3. Membuat matrik perbandingan berpasangan yang menggambarkan kontribusi relatif atau pengaruh setiap elemen terhadap tujuan atau kriteria yang setingkat di atasnya. Perbandingan dilakukan berdasarkan pilihan atau judgement dari pembuat keputusan dengan menilai tingkat kepentingan suatu elemen dibandingkan elemen lainnya.

4. Menormalkan data yaitu dengan membagi nilai dari setiap elemenp di dalam matrik yang berpasangan dengan nilai total dari setiap kolom.

5. Menghitung nilai eigen vector dan menguji konsistensinya, jika tidak konsisten maka pengambilan data (preferensi) perlu diulangi. Nilai eigen vector yang dimaksud adalah nilai eigen vector maksimum yang diperoleh.

6. Mengulangi langkah 3,4 dan 5 untuk seluruh tingkat hirarki.

7. Menghitung eigen vector dari setiap matriks perbandingan berpasangan. Nilai eigen vector merupakan bobot setiap elemen.

8. Menguji konsistensi hirarki. Jika tidak memenuhi dengan $\mathrm{CR}<0,100$ maka penilaian harus diulangi kembali.

Rumus Untuk Menentukan Rasio Konsistensi (CR) Indeks konsistensi dari matriks berordo $\mathrm{n}$ dapat diperoleh dengan rumus

$$
C I=\frac{\lambda_{\text {Maksimum }-n}}{n-1}
$$

Dimana :

$\mathrm{Cl} \quad=$ Indek konsistensi (Consistency Index)

$\lambda$ maksimum $=$ Nilai eigen terbesar dari matrik berordo $\mathrm{n}$

$\lambda$ maksimum didapat dengan menjumlahkan hasil perkalian jumlah kolom dengan eigen vektor utama.

Apabila C.I $=0$, berarti matriks konsisten.

Batas ketidakkonsistenan yang ditetapkan Saaty diukur dengan menggunakan rasio konsistensi $(\mathrm{CR})$, yakni perbandingan indek konsistensi dengan nilai pembangkit random (RI). Nilai $\mathrm{RI}$ bergantung pada ordo matrik $n$.

Tabel 1

Tabel Nilai RI

\begin{tabular}{|c|c|}
\hline $\mathrm{N}$ & $\mathrm{RI}$ \\
\hline 1 & 0.00 \\
\hline 2 & 0.00 \\
\hline 3 & 0.58 \\
\hline 4 & 0.90 \\
\hline 5 & 1.12 \\
\hline 6 & 1.24 \\
\hline 7 & 1.32 \\
\hline 8 & 1.41 \\
\hline 9 & 1.45 \\
\hline 10 & 1.49 \\
\hline 11 & 1.51 \\
\hline 12 & 1.58 \\
\hline
\end{tabular}

CR dirumuskan :

$$
C R=\frac{C I}{R I}
$$




\section{Hasil dan Pembahasan}

Sistem Penunjang Keputusan ini menggunakan metode AHP dan dimaksudkan untuk membantu dalam pengambilan keputusan untuk menentukan kualitas pakaian jadi. Dalam penentuan keputusan melakukan beberapa tahapan yaitu : penyusunan kriteria, pemilihan model dan perbandingan kriteria

\section{Penyusunan kriteria}

Kriteria :

ukuran, jahitan, material

Alternatif :

1. Ukuran panjang badan.

2. Ukuran lebar badan.

3. Ukuran panjang lengan.

4. Jahitan rapat, padat dan tebal

5. Jahitan ada keliman/lipatan

6. Jahitan harus rapih

7. Material kain tidak kusut atau tidak mulur

8. Material accesoris lengkap

9. Material packing tertutup dan rapih

Pembobotan :

Tabel 2

Nilai Bobot

\begin{tabular}{|c|c|c|c|c|}
\hline $\begin{array}{c}\text { Alt } \\
\text { ern } \\
\text { atif }\end{array}$ & $\begin{array}{c}\text { Sub } \\
\text { Altern } \\
\text { atif }\end{array}$ & $\begin{array}{c}\text { Keteran } \\
\text { gan }\end{array}$ & $\begin{array}{c}\text { Bo } \\
\text { bot }\end{array}$ & Grade \\
\hline 1 & a & $\begin{array}{c}\text { Sesuai / } \\
0\end{array}$ & 5 & A \\
\hline 1 & b & $\pm 1 / 2$ & 4 & B \\
\hline 1 & c & $\begin{array}{c}>\text { atau }< \\
\pm 1 / 2\end{array}$ & 3 & C \\
\hline 2 & a & $\begin{array}{c}\text { Sesuai / } \\
0\end{array}$ & 5 & A \\
\hline 2 & b & $\pm 1 / 4$ & 4 & B \\
\hline 2 & c & $\begin{array}{c}>\text { atau }< \\
\pm 1 / 4\end{array}$ & 3 & C \\
\hline 3 & a & $\begin{array}{c}\text { Sesuai / } \\
0\end{array}$ & 5 & A \\
\hline 3 & b & $\begin{array}{c} \pm 1 / 8 \\
\text { atau }< \\
\pm 1 / 8\end{array}$ & 4 & B \\
\hline 3 & C & C \\
\hline 4 & a & Rapat & 5 & A \\
\hline 4 & b & $\begin{array}{c}\text { Sedikit } \\
\text { rapat }\end{array}$ & 4 & B \\
\hline 4 & c & $\begin{array}{c}\text { Kurang } \\
\text { rapat }\end{array}$ & 3 & C \\
\hline
\end{tabular}

\begin{tabular}{|c|c|c|c|c|}
\hline 5 & a & $\begin{array}{c}\text { Keliman } \\
4 \mathrm{~cm}\end{array}$ & 5 & A \\
\hline 5 & $b$ & $\begin{array}{c}\text { Keliman } \\
2 \mathrm{~cm}\end{array}$ & 4 & B \\
\hline 5 & c & $\begin{array}{c}\text { Tidak } \\
\text { ada } \\
\text { keliman }\end{array}$ & 3 & C \\
\hline 6 & $a$ & $\begin{array}{c}\text { Sangat } \\
\text { rapih }\end{array}$ & 5 & A \\
\hline 6 & b & $\begin{array}{l}\text { Kurang } \\
\text { rapih }\end{array}$ & 4 & B \\
\hline 6 & C & $\begin{array}{l}\text { Tidak } \\
\text { rapih }\end{array}$ & 3 & C \\
\hline 7 & a & $\begin{array}{l}\text { Tidak } \\
\text { kusut }\end{array}$ & 5 & A \\
\hline 7 & $b$ & $\begin{array}{c}\text { Sedikit } \\
\text { kusut }\end{array}$ & 4 & B \\
\hline 7 & C & kusut & 3 & C \\
\hline 8 & $a$ & Komplit & 5 & A \\
\hline 8 & $b$ & $\begin{array}{l}\text { Kurang } \\
\text { Komplit }\end{array}$ & 4 & B \\
\hline 8 & c & $\begin{array}{c}\text { Tidak } \\
\text { Komplit }\end{array}$ & 3 & C \\
\hline 9 & $a$ & Tertutup & 5 & A \\
\hline 9 & $b$ & $\begin{array}{l}\text { Kurang } \\
\text { tertutup }\end{array}$ & 4 & B \\
\hline 9 & C & $\begin{array}{l}\text { Tidak } \\
\text { tertutup }\end{array}$ & 3 & C \\
\hline
\end{tabular}

Penentuan bobot dari kriteria sebagai berikut:

1. Alternatif 1: A1 : Ukuran panjang badan $=9$ (Sangat penting).

2. Alternatif 2: A2 : Ukuran lebar badan $=9$ (Sangat penting).

3. Alternatif 3: A3 : Ukuran panjang lengan $=7$ ( penting).

4. Alternatif $4: A 4:$ jahitan rapat $=9$ (Sangat penting).

5. Alternatif 5: A5: jahitan keliman $=6$ (sedikit penting).

6. Alternatif $6: A 6$ : jahitan rapih $=5$ (Sedikit penting).

7. Alternatif $7: A 7$ : Material kain $=7$ (penting).

8. Alternatif 8: A8 : Material Accesories $=7$ (penting).

9. Alternatif 9: $A 9$ : Material Packing = 6 (sedikit penting). 
Hasil analisis diperoleh perhitungan untuk semua kriteria yaitu :

1. Ukuran : Jahitan

$1: 4=8$, sangat penting

$1: 5=5$, sedikit penting

$1: 6=4$, agak penting

$2: 4=6$, cukup penting

$2: 5=4$, agak penting

$2: 6=2$, sama penting

$3: 4=4$, agak penting

$3: 5=3$, sedikit penting

$3: 6=3$, sedikit penting

2. Ukuran : Material

$1: 7=5$, cukup penting

$1: 8=5$, cukup penting

$1: 9=4$, sedikit penting

$2: 7=4$, sedkit penting

$2: 8=3$, agak penting

$2: 9=1$, sama penting

$3: 7=4$, sedikit penting

$3: 8=4$, sedikit penting

$3: 9=3$, agak penting

3. Jahitan : Material

$4: 7=1$, sama penting

$4: 8=2$, kurang penting

$4: 9=3$, agak penting

$5: 7=1$, sama penting

$5: 8=4$, sedkit penting

$5: 9=4$, sedkit penting

$6: 7=2$, kurang penting

$6: 8=2$, kurang penting

$6: 9=3$, agak penting

\section{Matrik perbandingan Berpasangan}

Perbandingan berpasangan dalam menentukan kualitas pakaian jadi. Kriteria :

1. Ukuran : panjang dan lebar badan

2. Jahitan : Kerapatan benang

3. Material : tidak kusut dan mulur

Dibawah ini merupakan matrik perbandingan untuk kriteria yang ditunjukkan.

Tabel 3

Matrik Perbandingan untuk kriteria

\begin{tabular}{|l|c|c|c|}
\hline & Ukuran & Jahitan & Material \\
\hline Ukuran & 1 & 8 & 5 \\
\hline Jahitan & $1 / 8$ & 1 & 1 \\
\hline Material & $1 / 5$ & $1 / 1$ & 1 \\
\hline
\end{tabular}

Selanjutnya matrik perbandingan untuk kriteria yang disederhanakan :

Tabel 4

Matrik Perbandingan untuk kriteria yang disederhanakan

\begin{tabular}{|l|c|c|c|}
\hline & Ukuran & Jahitan & Material \\
\hline Ukuran & 1 & 8 & 5 \\
\hline Jahitan & 0.125 & 1 & 1 \\
\hline Material & 0.2 & 1 & 1 \\
\hline$\sum$ Kolom & 1.325 & 10 & 7 \\
\hline
\end{tabular}




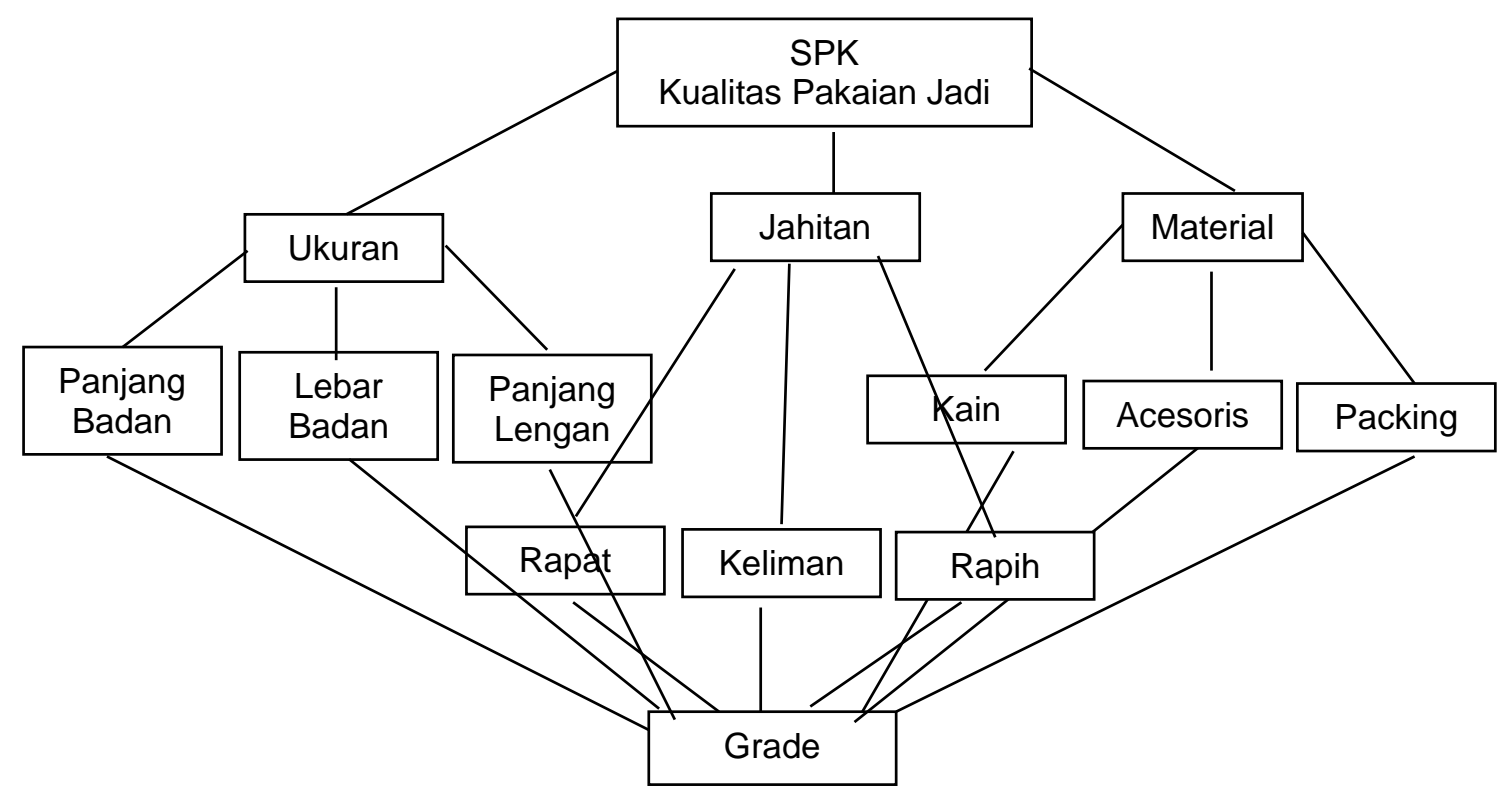

Gambar 1.

Hierarchy Keputusan

\section{Menormalkan data}

Dengan unsur - unsur pada tiap kolom dib agi dengan jumlah kolom total pada kolom yang bersangkutan, akan diperoleh bobot relatif yang dinormalkan.
Nilai vektor eigen dihasilkan dari rata-rata nilai bobot relative untuk tiap baris. Hasilnya dapat dilihat pada tabel berikut :

\section{Tabel 5}

Matrik Perbandingan untuk kriteria yang dinormalkan

\begin{tabular}{|c|c|c|c|c|c|}
\hline & Ukuran & Jahitan & Material & $\sum$ Baris & Eigen Vector \\
\hline Ukuran & 0.754 & 0.8 & 0.714 & 2.268 & 0.756 \\
\hline Jahitan & 0.094 & 0.1 & 0.142 & 0.336 & 0.112 \\
\hline Material & 0.150 & 0.1 & 0.142 & 0.392 & 0.132 \\
\hline
\end{tabular}

Berikut adalah perhitungan bobot relatif yang dinormalkan :
$1: 1.325=0.754$
$8: 10=0.8$
$0.125: 1.325=0.094$
$1: 10=0.1$
$0.2: 1.325=0.150$
$1: 10=0.0$ 
$5: 7=0.714$

$1: 7=0.142$

$1: 7=0.142$

\section{Menghitung Nilai Eigen Vector dan menguji Konsistensinya.}

Menghitung nilai Eigen Vector dan menguji konsistensinya, jika tidak konsisten maka pengambilan adat ( Prefensi ) perlu diulangi. Nilai Eigen Vector yang dimaksud adalah Nilai Eigen Vector maksimum yang diperoleh.

$$
\begin{aligned}
\text { Eigen Vektor Ukuran } & =\sum \text { Baris } / \text { kolom } \\
& =2.268 / 3 \\
& =0.756 \\
\text { Eigen Vektor Jahitan } & =\sum \text { Baris } / \text { kolom } \\
& =0.336 / 3 \\
& =0.112 \\
\text { Eigen Vektor Material } & =\Sigma \text { Baris } / \text { kolom } \\
& =0.392 / 3 \\
& =0.132
\end{aligned}
$$

Selanjutnya nilai eigen maksimum (

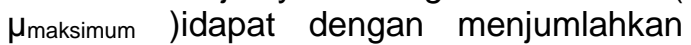
hasil perkalian jumlah kolom dengan eigen vektor. Nilai eigen maksimum yang dapat diperoleh adalah sebagai berikut :

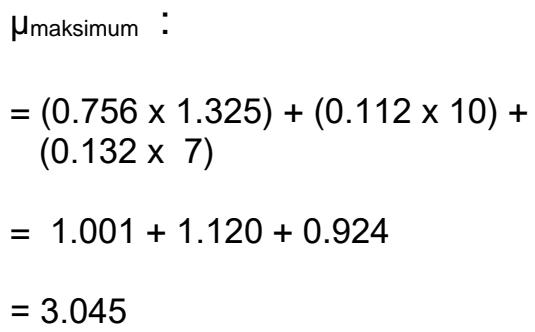

Karena matrik berordo 3 ( yakni terdiri dari 3 kolom ), maka indeks konsistensi ( $\mathrm{Cl}$ ) yang diperoleh :

$$
\begin{aligned}
& =\frac{0.045}{2} \\
& =0.026
\end{aligned}
$$

Untuk $\mathrm{n}=3, \mathrm{RI}=0.58$ (nilai tabel $\mathrm{RI}$ ), maka

$$
\begin{aligned}
& \quad C R=\frac{C I}{R I} \\
& =\frac{0.026}{0.58} \\
& =0.045<0.100
\end{aligned}
$$

Karena CR ( Rasio Konsistensi ) $<0.100$, maka hasil konsisten. Dari hasil perhitungan pada tabel diperoleh hasil :

Ukuran : $0.756 \times 100 \%=75.60 \%$

Jahitan : $0.112 \times 100 \%=11.2 \%$

Material : $0.132 \times 100 \%=13.2 \%$

Kriteria ukuran > $70 \%$ maka, kualitas pakaian jadi memiliki kualitas lebih penting daripada yang lain.

\section{Kesimpulan}

Sistem penunjang Keputusan untuk menentukan kualitas pakaian jadi di insustri garment sudah dapat melakukan perhitungan dengan metode AHP ( Analytic Hierarchy Process ) lebih cepat dibandingkan perhitungan secara manual sehingga bisa lebih efesien dan tingkat keakuratannya data baik.

Selanjutnya disarankan untuk peneliti yang akan datang supaya ditambahkan lagi untuk kriteria dan alternatif dan dibuatkan aplikasi SPK dengan metode AHP.

$$
\begin{aligned}
C I & =\frac{\lambda_{\text {Maksimum }-n}}{n-1} \\
& =\frac{3.045-3}{3-1}
\end{aligned}
$$




\section{Referensi}

Abadi. (2016). "Penentuan Penerima Bantuan Dana untuk Sekolah Menengah Di Kab. Banjar Menggunakan Metode AHPTOPSIS". Jurnal Speed- Sentra Penelitian Engeneering dan Edukasi, Vol. 8 No. 1.

Darmanto. (2014). "Penerapan Metode AHP (Analytic Hierarchy Process) untuk Menentukan Kualitas Gula Tumbuk". Jurnal SIMETRIS, Vol. 5 No. 1, April 2014, ISSN : 2252-4983.

Lemantara. (2013). "Rancang Bangun

Sistem Pendukung Keputusan Pemilihan Mahasiswa

Berprestasi Menggunakan Metode AHP dan Promethee". Jurnal JNTETI, Vol. 2 No. 1. ISSN 2301 - 4156.

O'Brien. 2008. Introduction to Information System, edition 12. (Pengantar Sistem Informasi Perspektif Bisnis dan Manajerial. Jakarta: PT. Salemba Empat (Emban Patria).

Montgomery, D.C. 2009. Introduction to Statistical Quality Control. Mc Graw Hill.
Prayoga. (2017). Sistem Pendukung Keputusan Pemilihan Supplier Botol Galon menggunakan Metode AHP". Jurnal Teknologi dana Manajemen Industri, Vol. 2 No. 2. Agustus 2017.

Saaty. 2018. The Analityc Hierarchy Process. McGraw Hill International.

Saragih. (2013). "Penerapan Metode AHP (Analytic Hierarchy Process) Pada Sistem Pendukung Keputusan Pemilihan Laptop Pelita Informatika Budi darma, Vol. IV No. 2, Agustus 2013, ISSN : 2301-9425.

Sestri. (2013). "Penilaian Kinerja Dosen Dengan Menggunakan Metode AHP ( Studi kasus : STIE Ahmad Dahlan Jakarta)".Jurnal Liquidity, Vol. 2 No. 1. Januari - juni 2013, Hal. 100-109.

Supriyanto. 2008. Pengantar Teknologi Informasi. Jakarta: Salemba Infotek. 